\title{
Difference of statuses of identity based on student's final year of career orientation in hasanuddin university
}

\author{
(Study on Departments that have / do not have a profession-based education program at \\ Hasanuddin University)
}

\author{
Muhammad Noerul Akhbar \\ Department of Psychology, Faculty of \\ Medicine \\ Hasanuddin University \\ Makassar, Indonesia \\ muhammadnoerulakhbar@gmail.com
}

\author{
Muhammad Tamar \\ Department of Psychology, \\ Faculty of Medicine \\ Hasanuddin University \\ Makassar, Indonesia
}

\author{
Wahid Hasyim \\ Department of Psychology, \\ Faculty of Medicine \\ Hasanuddin University \\ Makassar, Indonesia
}

\begin{abstract}
The purpose of this study is to obtain the following information: 1) the difference of statuses of identity based on final year student's career orientation at Hasanuddin University, and 2) differences in career orientation between final year students whose department has a profession-based education program with those whose departments do not have a profession-based education program Hasanuddin University. Participants are a minimal of sixth semester students from pharmacy, accounting, public health, and management bachelor's degree programs. Instruments of this study are career orientation inventory and EOMEIS-2. This study uses comparative analysis method, with one-way ANOVA test and independent t-test. The results of this study indicate that: 1) there is no difference of statuses of identity based on final year students' career orientations in Hasanuddin University, and 2) there is no difference in career orientation between final year students whose department has a profession-based education program with those whose departments do not have a professionbased education program Hasanuddin University.
\end{abstract}

Keywords - Career orientation; statuses of identity; profession; education

\section{INTRODUCTION}

College graduates should be ready to enter the workforce through the expected competencies. However, college graduates until now tend not to be able to fill the needs of the workforce due to lack of quality of work. The high unemployment rate of college graduates is a clear proof of the lack of quality that university graduates have, as the BPS [1] reports that the unemployment number of university graduates in August 2014 is 495.143 increased to 565.402 in February 2015.

Clear career orientation certainly affects the quality of college graduate work. Through a clear career orientation, college graduates are expected to have narrowed their career areas to make themselves focused on planning and exploring clearly in accordance with their career choices, so they have prepared for their career, including in the world of work [2].

Reality that occurs today is still a lot of students who are ahead of the final semester, even college graduates do not have a clear career orientation. Based on the results of research found that career orientation of final year students tend not be clear [3][4].

In general, there are two factors that affect the career orientation of students, namely internal factors and external factors. Both factors are composed of several factors [2].

One of the internal factors affecting career orientation is the development stage [2]. Every man should be able to complete the tasks at each stage of the development that he experienced so as not to impede the task of further development. Identity is one of the developmental tasks of teenagers that will affect the individual as an adult later. Identity confusion experienced by teenagers will certainly affect the success in completion of tasks at later stages of development including the task at the stage of career development. 
Meanwhile, one of the external factors affecting career orientation is school [2]. The allegation appears that educational programs that have professions have students with a clear career orientation compared to educational programs that do not have a profession. This is based on Indonesian law no. 12, Year 2012 Article 17 [5] which explains that professional education is higher education after the bachelor, prepared students in jobs that require special skill requirements. Therefore, educational programs that have a profession lead students towards a particular career/occupation more than educational programs that do not have a profession. Thus, students with educational programs that have a profession will be easier to make career planning.

Therefore, the purpose of this study is to obtain the following information:

1) The difference of statuses of identity based on final year student's career orientation at Hasanuddin University, and 2) the differences in career orientation between final years students whose department has a profession-based education program with those whose departments do not have a profession-based education program. The benefits of this research is to contribute to the psychological science, especially with career development. In addition, this research could become evaluation generally in the system were implemented in career guidance as well become consideration for stakeholders to draw up a follow-up program in an effort to help students have a clear career orientation

\section{LITERATURE REVIEW}

\section{A. Career Orientation}

Career orientation is defined as individual readiness in making the right career decisions [2]. Career orientation termed as the total score of the dimensions of career planning, career exploration, decision making, and world of work information, which is contained in the measuring instrument career development inventory [2]. Objectively, the dimensions of career orientation consists of two aspects: the development of attitudes toward career, which consists of career planning and career exploration, as well as aspects of the development of knowledge and career skills that consists of decision-making and world of work information [2].

\section{B. Statuses of Identity}

There are two characteristics of identity such as: crisis/exploration and commitment [6][7][8][9][10]. Crisis/exploration is a period of identity development when adolescents making a choice from several alternatives. Commitment is a psychological investment in an action or ideology [7][9]. Then, based on two characteristics, then Marcia forming four identity status, namely: identity achievement, identity moratorium, foreclosure identity, and identity diffusion [8][9][10].

\section{METHOD}

\section{A. Participants}

Participants were a minimal of sixth semester students from pharmacy, accounting, public health, and management bachelor's degree programs in Hasanuddin University. Total participants were 200 students. Determination of educational program used purposive sampling. Determination of a minimal of sixth semester students as a participants of research was based on the consideration that they will soon complete the study and will face career options, such as choosing work, continuing education, etc. Sampling method used nonprobability sampling by using accidental sampling technique.

\section{B. Procedures}

Initially, research instruments spread to the subject of research through Google form, with the results obtained 121 subjects of research. Because the number of subjects that are still needed, then the other effort is to go one by one subject of research directly, which finally get the total subject of 200 subjects.

\section{Measures}

Some of the instruments used in this study were: First, using adaptation and modification of career orientation inventory from Gunawan [4] based on Career Development Inventory (CDI College Version). Second, using an adapted and modified questionnaire from the Extended Version of the Objective Measure of Ego-Identity Status (EOMEIS-2) developed by Layne Bennion and Gerald Adam is based on James Marcia's theory [6][11]. Specially, EOMEIS-2 performed over the language, starting from forward translation by an official English institution, then also translation of two English linguist's educational background in psychology. After that, the instrument through the expert judgment process by several lecturers who are considered competent in relation to this research to validate the contents for the two measuring instruments to be used, whether the item has been in accordance with the theory used. Then, the measuring tool is given to five final students to assess the instruments that have been prepared, including: language of instruction, as well as item language. All of the instruments used in this study were through the validity and composite reliability test by using confirmatory factor analysis (CFA) through LISREL 8.70 (Linear Structural Relationship) program.

Table 1. Blue-print of career orientation instrument

\begin{tabular}{|l|c|c|}
\hline \multicolumn{1}{|c|}{ Dimension } & $\begin{array}{c}\text { Valid } \\
\text { items }\end{array}$ & Reliability \\
\hline Career planning & 20 & 0.99 \\
\hline Career exploration & 17 & 0.98 \\
\hline Decision making w work & 16 & 0.99 \\
\hline $\begin{array}{l}\text { World of } \\
\text { information }\end{array}$ & 11 & 0.98 \\
\hline
\end{tabular}

Table 2. Blue print of identity statuses instrument

\begin{tabular}{|l|c|c|}
\hline Dimension & $\begin{array}{c}\text { Valid } \\
\text { items }\end{array}$ & Reliability \\
\hline Achievement & 16 & 0.98 \\
\hline
\end{tabular}




\begin{tabular}{|l|l|l|}
\hline Moratorium & 16 & 0.98 \\
\hline Foreclosure & 16 & 0.98 \\
\hline Diffusion & 15 & 0.97 \\
\hline
\end{tabular}

\section{RESULTS}

\section{A. Study 1}

Table 3. The significance value of identity statuses based on career orientation

\begin{tabular}{|l|c|}
\hline \multicolumn{1}{|c|}{ Identity Statuses } & Significance \\
\hline Achievement & 0.02 \\
\hline Moratorium & 0.976 \\
\hline Foreclosure & 0.098 \\
\hline Diffusion & 0.032 \\
\hline
\end{tabular}

Based on table 3 , it can be concluded that there is no difference of statuses of identity based on final year students' career orientations in Hasanuddin University. Although there are two statuses of identity that have differences based on final year student's career orientation in Hasanuddin University, namely achievement identity and diffusion identity. However, there are two statuses of identity that do not have differences based on final year student's career orientation in Hasanuddin University, namely moratorium identity and foreclosure identity.

\section{B. Study 2}

Table 4. The significance value of the differences in career orientation

\begin{tabular}{|l|c|}
\hline \multicolumn{1}{|c|}{ Participants } & Significance \\
\cline { 1 - 1 } Pharmacy & 0.085 \\
\cline { 1 - 1 } Public Health & 0.826 \\
\hline Accounting & 0.826 \\
\cline { 1 - 1 } Management & \\
\hline
\end{tabular}

Based on table 4, it can be concluded that there is no difference in career orientation between final year students whose department has a profession-based education program with those whose departments do not have a profession-based education program in Hasanuddin University.

\section{DISCUSSION}

\section{A. Study 1}

Although the results of this study indicate that not all identity statuses differed based on final year student's career orientation in Hasanuddin University, the results of this study remain consistent with the Super theory explained one of the factors in career orientation is the development stage, particularly the identity status of the individual [2].

Individuals with an achievement identity have successfully explored and considerate about themselves and already know what they want to do in the future [6][7][8][9][10].

Thus, the individual already knows the exact direction of his career and has prepared himself with an exploration of his career expectations. In contrast, individuals who have diffusion identity do not explore alternative and committed $[6][7][8][9][10]$. Individuals with this identity status seem to be ignorant, not want / unable to determine the direction of his career, let alone in terms of exploring the desired career field. Thus, individuals who have diffusion identity are unable to fill the criteria of career orientation dimensions. Unlike the moratorium identity and foreclosure identity, which has at least one aspect of two aspects of identity status: exploration and commitment [6][7][8][9][10].

\section{B. Study 2}

The results of this study contradict one of the factors that affect the career orientation, namely school. Nevertheless, Super [2] does explain that career orientation is influenced by many factors, both inner and environmental factors. There are several factors that can contribute to the results of this study. First, the selection factor of students majors towards the department that is being lived. Decision making in choosing the students majors in Indonesia is not derived from the decision of parents or family, or initially just follow the close friend, not based on interest so that many students who experience " incompatibility". According to Educational Psychologist, Irene Guntur, M.Psi., Psi., CGA, from Integrity Development Flexibility (IDF), as many as 87 percent of students in Indonesia are mismanaged [12]. Selection of educational programs not based on interest will certainly have impacts for the student. Super [2] has also confirmed one of the factors affecting career orientation is interest.

The second factor that can contribute to the results is society. One of the factors influencing career orientation is society [2]. The participants of each educational program in this study originated from different regional origins by representing their respective cultures, such as Makassar, Maros, Pangkep, Barru, Gowa, Takalar, Jeneponto, Bantaeng, Bone, Pare-Pare, Pinrang, Soppeng, Bulukumba, Etc. The existence of environmental factor like cultural or society contribute to career orientation [8].

Then, the third factor that can contribute to the results is the aspirations of the faculty or university. The faculty or university aspirations include: curriculum formulation, lecturer competency, student facilities such as library content, related institutions that can accept students in real work/apprenticeship, and job market [13]. Perhaps, based on curriculum formulation, department that has a professionbased education program has a more prominent and specific curriculum formulation to deliver their students have the competencies expected by the profession. Nevertheless, to have a student with a clear career orientation, support is not only required in the curriculum formulation, but also needed support based on lecturer competence, even facilities such as library content, career counselling, Etc. In reality, the participant's university has only one counselling site, so this condition does not allow its reach in serving students who want to do career consultation, considering the number of students from this university that reach tens of thousands. Whereas, the research results prove that there is influence of counselling guidance to career orientation [14][15]. Finally, 
although various results have been obtained from this study, there are limitations in this study, such as 1) the method of selecting participants using a non-randomized participants so that this study cannot be applied outside of the study population; 2) lack of control over participants, such as culture.

\section{REFERENCES}

[1] BPS - Badan Pusat Statistik, "Pengangguran Terbuka Menurut Pendidikan Tertinggi yang Ditamatkan 1986 - 2017". Internet: https://www.bps.go.id/linkTabelStatis/view/id/972, 2015 [July. 27, 2017].

[2] Sharf, R. S. Applying career development theory to counselling. USA: Brooks/Cole Publishing Company. 2006.

[3] Azhar E.H., Zahroturrusyida H., and Marina S. "Gambaran Kematangan Karir Pada Para Calon Sarjana Di Lingkungan Fakultas Pikologi Universitas Padjadjaran”. Bachelor Thesis, Padjajaran University, Bandung, Indonesia. 2006.

[4] Gunawan, A. "Rancangan program intervensi untuk meningkatkan kesiapan mahasiswa dalam menghadapi pilihan karir”. M.S. thesis. Padjadjaran University, Bandung, Indonesia. 2011.

[5] Indonesian Government. Undang-Undang Republik Indonesia no.12 Tahun 2012 tentang Pendidikan Tinggi. State Secretariat, Jakarta, 2012.

[6] Adams, G. R. Objective measure of ego-identity status: A reference manual. Ontario: University of Guelp. 1998.

[7] Feldman, R. S. Development across the life span, $5^{\text {th }}$ Ed. USA: Pearson Education. 2009.
[8] Marcia, J. E., Archer, S. L., Waterman, A. S., Orlofsky, J. L., and Matteson, D. R. Ego Identity. A Handbook for Psychological Research. New York: Springer Verlag. 1993.

[9] Marcia, J.E. "Determination and construct validity of ego identity status". Doctoral Dissertations, The Ohio State University, Columbus, 1964.

[10]Santrock, J. W. Life-span development, $13^{\text {th }}$ Ed. New York: McGraw-Hill, 2011.

[11]Bennion, L. D. "Measuring Adolescent Ego-Identity Status: A Comparison of the Semi Structured Interview and the Objective Measure of Ego-Identity Status". M.S Thesis, Utah State University, Utah. 1988.

[12]Harahap, R. F. "Duh, 87\% Mahasiswa Indonesia Salah Jurusan!"https://news.okezone.com/read/2014/02/24/373/945961/ duh-87-mahasiswa-indonesia-salah-jurusan, Feb. 25, 2014 [August. 1, 2017]

13]Amin, Z. N. Wibowo, M. E., and Nusantoro, E. "Perbandingan orientasi karir siswa keturunan jawa dengan siswa ketrurunan tionghoa". Indonesian Journal of Guidance and Counselling: Theory and Application, vol.3, 2014.

[14]Sumantri, D. "Pengaruh faktor aspirasi pekerjaan dan aspirasi jurursan terhadap kematangan karir siswa smk jurursan otomotif di DIY 2012/2013". Bachelor Thesis. Yogyakarta State University, Yogyakarta, Indonesia. 2013.

[15]Juwitaningrum, I. (2013). "Program bimbingan karir untuk meningkatkan kematangan karir siswa smk (dikembangkan berdasarkan studi tentang kematangan karir siswa kelas x smkn 11 banding tahun ajaran 2010/2011". Journal of guidance and counselling psikopedagogia, vol.2, 2013.

[16]Sudjani. "Faktor-faktor yang mempengaruhi kematangan karir siswa sekolah menengah kejuruan negeri di kota bandung." National convention APTEKINDO VII, 2014, pp 1068-1075. 